TITLE:

\title{
Short-chain chlorinated paraffins in cooking oil and related products from China(Abstract_要旨 )
}

\author{
AUTHOR(S): \\ Cao, Yang
}

\section{CITATION:}

Cao, Yang. Short-chain chlorinated paraffins in cooking oil and related products from China. 京都大学, 2016, 博士 (社会健康医学)

ISSUE DATE:

2016-09-23

URL:

https://doi.org/10.14989/doctor.k19968

\section{RIGHT:}

Final publication is available at

http://dx.doi.org/10.1016/j.chemosphere.2015.05.063. 


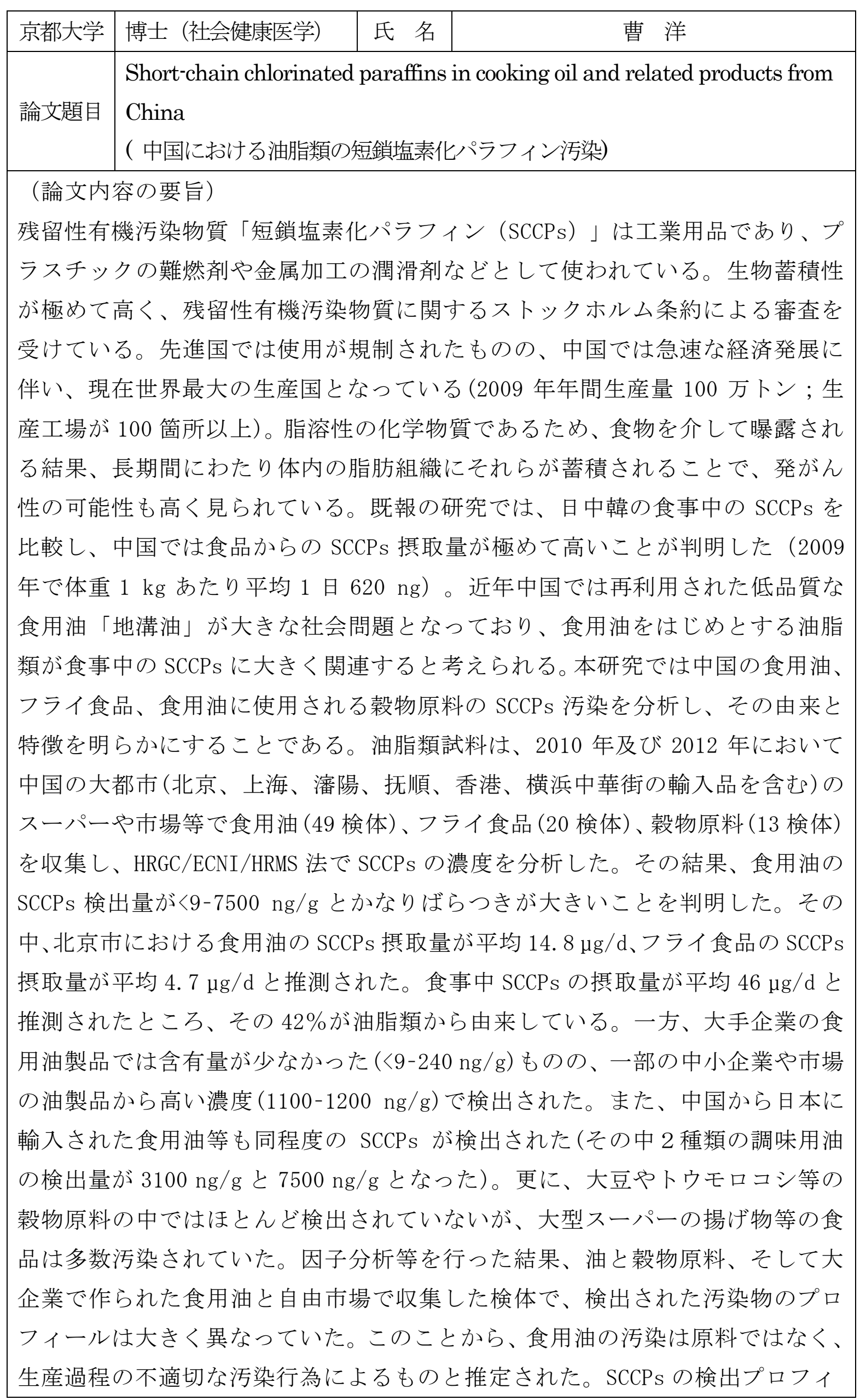

ールから、社会問題となった再生食用油「地溝油」の判明に繋がると考える。 生産活動による有害な化学物質が日常の食生活に紛孔込むことは深刻な社会課 題となるため、引き続き食事検体を追加評価していくことが必要である。

\section{(論文審査の結果の要旨)}

短鎖塩素化パラフィン $(\mathrm{SCCPs})$ はプラスチックの難燃剂や金属加 工の潤滑剂などに使われている工業用品であり、生物蓄積性が極めて高 い。中国では使用量が多く、食事からの摂取量は日本、韓国より高い。 本研究では中国の食用油、フライ食品、食用油に使用される穀物原料の SCCPs污染を分析し、その由来と特徴を明らかにした。

油脂類試料は、中国の大都市のスーパーや市場等で食用油(49検体)、 フライ食品 (20検体)、穀物原料(13検体)を収集し、HRGC/ECNI/HRMS 法でSCCPsの濃度を分析した。その結果、食用油の SCCPs検出量が <9-7500 ng/gとばらつきが大きかった。北京市における食用油からの $\mathrm{SCCPs}$ 摂取量が平均 $14.8 \mu \mathrm{g} / \mathrm{d}$ 、フライ食品からの $\mathrm{SCCPs}$ 摂取量が平均 $4.7 \mu \mathrm{g} / \mathrm{d}$ と推測された。

更に、大豆やトウモロコシ等の穀物原料の中ではほとんど検出され ていないが、大型スーパーの揚げ物等の食品は多数污染されていた。因 子分析等を行った結果、油と穀物原料、そして大企業で作られた食用油 と自由市場で収集した検体で、検出された污染物のプロフィールは大き く異なっていた。このことから、食用油の污染は原料ではなく、生産過 程の不適切な污染行為によるものと推定された。

以上の研究は中国における油脂類摂取による短鎖塩素化パラフィン 曝露の評価に貢献し、そのリスク管理に寄与するところが多い。

したがって、本論文は博士（社会健康医学）の学位論文として価值あるも のと認める。

なお、本学位授与申請者は、平成 28 年 6 月 24 日実施の論文内容と それに関連した試問を受け、合格と認められたものである。

要旨公開可能日： 年 月 日 以降

